成にほとんど無関保であり，したがって塭基珄質とす咸係がな い。 $\mathrm{MgO} / \mathrm{Al}_{2} \mathrm{O}_{3}$ のモル比が 20 のすのは活活性を示すのに $\mathrm{MgO}$

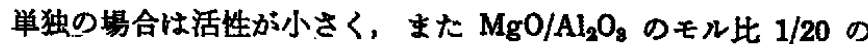

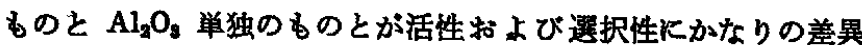
を示すことから，この三元酸化物は $\mathrm{Al}_{2} \mathrm{O}_{3}$ および $\mathrm{MgO}$ 単独で
は見られない触媒作用を示したといいらる。しかしてルキル化反 応火詨する活性点はジアセトンアルコールの分解反㤁の活性点 のよらに単純ではなく，図 2 の塩基性の結果と表 1 の結果から㙁 基性のみならず，他の表面性筫る活性㴨関俰していると推察され ๖。

\title{
The Decomposition of Diacetone Alcohol and the Alkylation of Phenol with Methanol Catalyzed by $\mathrm{MgO}-\mathrm{Al}_{2} \mathrm{O}_{3}$ Catalysts
}

\author{
Yasuo Fukuda, Tadao Nishizaki and Kozo Tanabe \\ Department of Chemistry, Faculty of Science, Hokkaido University; \\ Sapporo-shi, Japan
}

The catalytic activities of $\mathrm{MgO}-\mathrm{Al}_{2} \mathrm{O}_{8}$ with various compositions for the title reactions have been examined. The $\mathrm{MgO}-\mathrm{Al}_{2} \mathrm{O}_{3}$ of molar ratio 20 showed a maximum activity for the decomposition of diacetone alcohol when calcined at $400^{\circ} \mathrm{C}$, the activity being greater than that of $\mathrm{MgO}$. The activity was found to correlate with the basicity of the catalysts. The activity for the alkylation of phenol increased with increase of the $\mathrm{MgO}$ content, the highest activity being observed for $\mathrm{MgO}-\mathrm{Al}_{2} \mathrm{O}_{3}$ of molar ratio 20 where the yield of 0 -cresol was $66 \%$. The activity was entirely different from that of $\mathrm{MgO}$ or $\mathrm{Al}_{2} \mathrm{O}_{3}$. The basicity of $\mathrm{MgO}-\mathrm{Al}_{2} \mathrm{O}_{3}$ correlated with the activity, but not with the selectivity.

\section{3-メトキシジフェニレンオキシドの Friedel-Crafts アシル化の配 向122}

（1972 年 5 月 24 日受理）

\author{
毛海 敬・滝見宣彦・大島好文*
}

\begin{abstract}
1 綿 带
メトキシジフェニレンオキシド類は親電子試薬に対し反応 性 で，置換される場所が多く考えられその配向性は興味深い。2-メ トキシジフェニレンオキシドのニトロ化3), ハロゲン化(4), Friedel-Crafts アシル化 ${ }^{2)}$ は優先的に 3-位へ，一部 1-位へ起こる。 3-メトキシジフェニレンオキシド[1]の親䉓子試薬に対する配 向性については報告がない。著者らは [1]の Friedel-Crafts アセチル化, ヘンソ゚イル化を行ない，その配向位首を決定した。
\end{abstract}

\section{2 実験}

\section{1 試 料}

[1]は 3-アミノジフェニレンオキシドをジアゾ化, 加水分解

1）この報文を“ジフェニレンオキシド誘導体に関する研究 (第 16 報)”とする.

2）前報(第 15 報)，毛海 敬，出田浙雄, 大島好文, 日化, 1972, 1438.

* 福井大学工学部㵶維染料学科, 福井市文京町

3) K. Schimmelschmidt, Ann., 566, 184(1950).

4) H. Gilman, P. R. Van Ess, J. Amer. Chem. Soc., 61, 1365 (1939).
し3-ヒドロキシジフェニレンオキシド5)とし， $p$-トルエンスルホ ン酸メチルでメチル化し合成した。 mp 95.5 97 ${ }^{\circ} \mathrm{C}^{6)}$ 。アシル化 剂は市販品を蒸留した塩化アセチル, bp $49 \sim 53^{\circ} \mathrm{C}$, 塩化ベンジ イル bp 93〜94 ${ }^{\circ} \mathrm{C} / 29 \sim 30 \mathrm{mmHg}$ を使用した。

2.2 [1]の Friedel-Crafts アセチル化

[1] $2.0 \mathrm{~g}(0.010 \mathrm{~mol})$, 無水塩化アルミニウム $2.0 \mathrm{~g}(0.015$ $\mathrm{mol})$ のニトロベンゼン $30 \mathrm{ml}$ 溶液へ，15 20 $20^{\circ} \mathrm{C}$ で塩化アセチ ル $1.2 \mathrm{~g}(0.015 \mathrm{~mol})$ を滴下し，1時間かきぜたのち，常法の 処理をし粗製の 2-アセキルー3-メトキシジフェニレンオキシド [2] $2.4 \mathrm{~g}\left(\mathrm{mp} \mathrm{106} \mathrm{108}{ }^{\circ} \mathrm{C}\right.$, 取率 99.2\%) を得た。アルコー ル・水 (容量比 $5: 2$ ) 混合溶媒加ら再結晶 L, [2] $2.1 \mathrm{~g}(\mathrm{mp}$ $109 \sim 110^{\circ} \mathrm{C}$, 取率 $86.0 \%$ ) を得た。さらに再結晶すると精製品 ( $\mathrm{mp} 110 \sim 111^{\circ} \mathrm{C}$ ) を得る。

\section{3 [I]の Friedel-Crafts ベンソイル化}

[1] $2.5 \mathrm{~g}(0.013 \mathrm{~mol})$, 無水塩化アルミニウム $2.6 \mathrm{~g}(0.019$ $\mathrm{mol})$ のニトロベンゼン $30 \mathrm{ml}$ 溶液へ, $15 \sim 20^{\circ} \mathrm{C}$ で塩化ベンゾ

5） F. P., 768, 052; 大島好文, 福井大学工学部研究報告, 13, 206(1965).

6) K. Tatematsu, B. Kubota, Bull. Chem. Soc. Jap., 9, 448 (1934). 


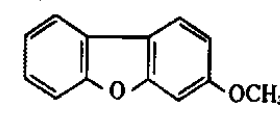

[1]<smiles>COc1cc2oc3ccccc3c2cc1Oc1ccccc1</smiles>

[3]<smiles>COc1cc2oc3cc(C4CCCCC4)ccc3c2cc1C(C)=O</smiles>

[2]

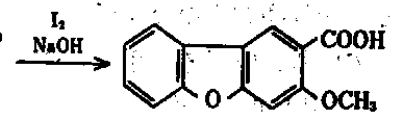

[4]

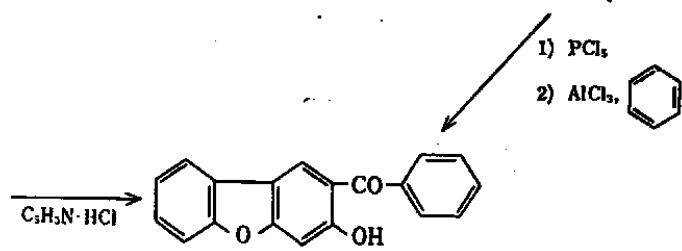

[5]

Fig. 1

Table 1 Properties of the products

\begin{tabular}{|c|c|c|c|c|c|c|c|c|c|c|c|c|c|c|}
\hline \multirow{3}{*}{$\begin{array}{l}\text { Com- } \\
\text { pound }\end{array}$} & \multirow{3}{*}{$\begin{array}{l}\text { Solv. for } \\
\text { recryst. }\end{array}$} & \multirow{3}{*}{$\underset{\left({ }^{\circ} \mathrm{C}\right)}{\mathrm{mp}}$} & \multicolumn{4}{|c|}{ Elemental analysis } & \multirow{2}{*}{\multicolumn{3}{|c|}{$\operatorname{IR}(\mathrm{KBr})\left(\mathrm{cm}^{-1}\right)$}} & \multirow{2}{*}{\multicolumn{2}{|c|}{$\mathrm{UV}(\mathrm{EtOH})$}} & \multirow{2}{*}{\multicolumn{3}{|c|}{ NMR $\delta$ (ppm) }} \\
\hline & & & \multicolumn{2}{|c|}{ Found (\%) } & \multicolumn{2}{|c|}{ Calcd. $(\%)$} & & & & & & & & \\
\hline & & & $\mathrm{C}$ & $\mathrm{H}$ & C & $\mathrm{H}$ & $\nu_{c=0}$ & $\delta_{4 \mathrm{CH}}$ & $\nu_{\mathrm{OH}}$ & $\lambda_{\max }$ & $\varepsilon \times 10^{4}$ & $\mathrm{COCH}_{3}$ & $\mathbf{O H}$ & $\mathrm{OCH}_{8}$ \\
\hline$[2]$ & $\mathrm{C}_{2} \mathrm{H}_{6} \mathrm{OH} \cdot \mathrm{H}_{2} \mathrm{O}$ & $110 \sim 111$ & $74 . \dot{81}$ & 5.07 & 74.98 & 5. 03 & 1673 & 750 & - & $\begin{array}{l}238.0 \\
256.0 \\
289.0 \\
297.0 \\
324.0\end{array}$ & $\begin{array}{l}2.77 \\
3.33 \\
1.03 \\
1.15 \\
0.55\end{array}$ & 2. 55 & $\begin{array}{l}\cdots \\
-\end{array}$ & $3.9^{(9)}$ \\
\hline$[3]$ & $\mathrm{C}_{2} \mathrm{H}_{5} \mathrm{OH}$ & $153 \sim 154$ & 79. 37 & 4.79 & 79. 46 & 4. 67 & 1654 & 750 & 一 & $\begin{array}{l}253.0 \\
298.0\end{array}$ & $\begin{array}{l}3.40 \\
1.90\end{array}$ & - & - & $3.74^{a)}$ \\
\hline [4] & $\mathrm{C}_{2} \mathrm{H}_{6} \mathrm{OH} \cdot \mathrm{H}_{2} \mathrm{O}$ & $199 \sim 200$ & 69.21 & 4. 18 & 69.42 & 4. 16 & 1704 & 750 & 3100 & $\begin{array}{r}231.0 \\
249.0 \\
290.0 \\
297.0 \\
313.0\end{array}$ & $\begin{array}{l}3.51 \\
2.67 \\
1.20 \\
1.42 \\
0.89\end{array}$ & - & - & - \\
\hline$[5]$ & $\mathrm{C}_{2} \mathrm{H}_{5} \mathrm{OH}$ & $\begin{array}{l}201 \sim \\
201.5\end{array}$ & 78.92 & 4. 36 & 79.16 & 4. 20 & 1650 & 750 & 一 & $\begin{array}{l}234.2 \\
275.0\end{array}$ & $\begin{array}{l}2.70 \\
3.6\end{array}$ & 一 & 一 & - \\
\hline$[6]$ & $\mathrm{CH}_{3} \mathrm{OH} \cdot \mathrm{H}_{2} \mathrm{O}$ & $\stackrel{176 \sim}{176.5}$ & 79.01 & 4. 36 & 79.16 & 4. 20 & 1638 & - & 3220 & $\begin{array}{l}253.0 \\
307.0\end{array}$ & $\begin{array}{l}3.30 \\
1.90\end{array}$ & - & 8. 43 & $-b$ \\
\hline
\end{tabular}

イル $2.7 \mathrm{~g}(0.019 \mathrm{~mol})$ を滴下し，I時間かきまぜたのち，常法 の処理をし，粗製の 3ーメトキシー2-ペンゾイルジフェニレンオキ シド [3] $3.8 \mathrm{~g}\left(\mathrm{mp} 145 \sim 150^{\circ} \mathrm{C}\right.$, 収率 100\%) を得た。アルコ 一ル $4 \mathrm{ml}$ で熱時口過し，口夜残分として [3] $3.2 \mathrm{~g}$ (mp 150 $\sim 152^{\circ} \mathrm{C}$, 収率 $89.6 \%$ ) を得だ。アルコールから再結晶すると精 製品 (mp 153 $\left.154^{\circ} \mathrm{C}\right)$ を得る。

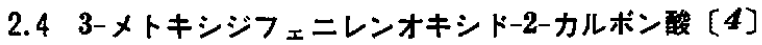

ヨードホルム反応の一般法に 準じで（2] $1.0 \mathrm{~g}$ から粗製の [4] $0.5 \mathrm{~g}\left(\mathrm{mp} 191 \sim 193^{\circ} \mathrm{C}\right.$, 收率 $\left.50.0 \%\right)$ t得た。アルコール ・水 (容量比 $1: 1$ ) から再結晶すると精製品 (mp 199 200 ${ }^{\circ} \mathrm{C}$ ) を得る。

2.5 2-ベンソイルー3ーヒドロキシジフェニレンオキシド[5]

[3] $2.0 \mathrm{~g}$ とピリジン湓酸塩 $1.7 \mathrm{~g}$ の混合物を 2 時間焦沸し,

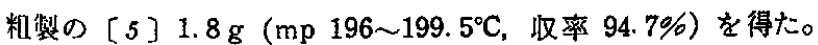
アルコールから再結晶すると精製品 $\left(\mathrm{mp} \mathrm{201} 201.5^{\circ} \mathrm{C}\right)$ を得る。 一方，〔4]0.3 g, 五塩化レン $0.3 \mathrm{~g}$, ベンゼン $4 \mathrm{ml}$ を加熱し, 生成した〔4] の酸クロリドへ, ベンゼン $30 \mathrm{ml}$, 無本塩化アル ミニウム $0.3 \mathrm{~g}$ を加え， 3 特間煮沸，常法の処理を経て得られた 3-ヒドロキシーペンゾイルジフェニレンオキシド（mp 200 201 ${ }^{\circ} \mathrm{C}$, 収率 26.0\%) は [5] と同一物であった（混融試験，IR ス ペクトル)。

7) Cl. Routier, Ng. PH. Buu-Hoï, R. Royer, J.Chem. Soc., 1956. 4276.
2.6 3-ヒドロキシ-8-ベンソイルジフェニレンオキシド [6] 煮沸した $15 \%$ 硫酸水溶液 $120 \mathrm{ml}$ へ3-アミノ-8-ベンゾイル ジフェニレンオキシド8 [7] $4.0 \mathrm{~g}$ のジアジニウム硫酸塩水溶液 を滴下し，3 時間堂沸後，常法の処理をし粗製の [6] $1.5 \mathrm{~g}(\mathrm{mp}$ 164. 5 166. $5^{\circ} \mathrm{C}$, 取率 $37.5 \%$ ) を得た。メタノール・水（容量比 $2: 1 ）$ 混合溶媒から再結晶すると精製品 (mp 176 176. $\left.5^{\circ} \mathrm{C}\right)$ を 得る。

\section{3 結果と考案}

[1]の Friedel-Crafts アセチル化, ベンジイル化反沈の生成 物〔2]，[3]の構造は図1亿示方法によって決定した。精製 品の諸性筫は表 1 に示した。

[1], 塩化ベンゾイル, 無水塩化アルミニウムをモル比 1 : $1.5: 1.5$, ニトロベンゼン溶某, 室温で 1 時間反応させ, $\mathrm{mp}$ 153 $154^{\circ} \mathrm{C}$ の[3] を精製収率 $89.6 \%$ で得た。この脱メチル化

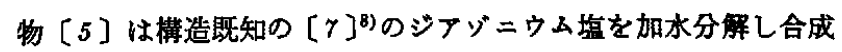

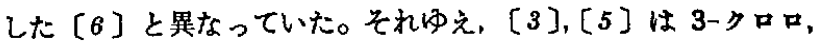
3-ブロモ，3-アセトアミドジフェニレンオキシドのベンヅイル 化8 のように 8-位へ反応したるのではない。それらの IR スペク トルでは芳香族 $\delta_{4 \mathrm{CH}}$ に基づく $750 \mathrm{~cm}^{-1}$ の吸収があり，[5]の $\nu_{\mathrm{C}=0}$ は[6]のそれにくらべ高波数側にあり，将 の吸収がな

8）毛海敬，山田浙雄，野田秀炤，大島好文，日化，1972, 387. 
くアルカリに難溶性である。それゆえそのカルボニル基はとドロ キシ基と分子内水素結合しているといえる。また，ジフェニレン オキシドの脱トリキウム化2)，脱シリル化 ${ }^{109}$ の部分速度因子から， 4-位は 2-位にくらべ親電子試薬に対しきわめて反応性が低い。 これらのことから[3]，[5]のベンゾイル基は 2-位㑑入され たものであると結論した。ベンジイル化と同様，〔1]と塩化】

9) R. Baker, C. Eaborn, J. Chem. Soc., .1961, 5077.

10) C. Eaborn, J. A. Sperry, ibid., 1961, 4921.

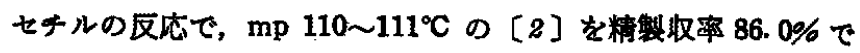

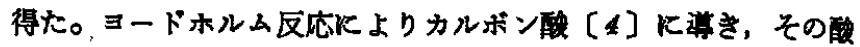
クロリドとベンゼンの Friedel-Crafts 反応から[5] と同一物 を得た。

以上のことから，[1].の Friedel-Crafts アセチル化，ベンッ゙ イル化性他の 3-置換ジフェニレンオキシドのベンジイル化各と翼. なり，置換基のオルト位の 2-位へ配向することを明らかにした。

\section{Orientation in the Friedel-Crafts Acylation of 3-Methoxydiphenylene Oxidet}

Takashi Keumi, Nobuhiko Takimi and Yoshibumi Oshima

Department of Fiber and Dyestuff. Faculty of Engineering Fukui University; Bunkyo, Fukui-shi, Japan

Orientation in the Friedel-Crafts acylation of 3-methoxydiphenylene oxide [1] was studied. The reaction of $I$ with acetyl chloride in the presence of aluminium chloride in nitrobenzene was carried out at $20^{\circ} \mathrm{C}$ for $1 \mathrm{hr}, 2$-acetyl-3-methoxydiphenylene oxide was obtained in $86 \%$ yield. The site of acylation of I was elucidated. Similarly, the reaction with benzoyl chloride, 2-benzoyl-3-methoxydiphenylene oxide was obtained in $90 \%$ yield.

† Studies on Derivatives of Diphenylene Oxide. XVI.

\section{trans-4-メドキシスチルベンオキシドの 安息香酸による開環反応}

(1972 年 6 月 5 日受 理)

伊藤 正 英*

\section{1 腥 言}

Curtin 51) trans-4-メトキシスチルベンオキシド [1]を クロロホルム中安息香酸と反店させると立体配置を保持した開環 生成物であるスレオージオールモノベンゾアート[2]が得られる と述べているが，その構造が [2a] か [2b] か炕ついては言及 していない。

一方，Parker ら29この反心に二回反転譏構を考市ており， それによればその生成物は[2a]であるはずである。今回著者は

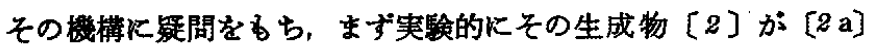
か [2 b] かをきめるため実験を行なったところ, Parker らの説 とは異なる結果が得られた。

* 弘前大学理学部化学科, 弘前市文亲町

1) D. Y. Curtin, A. Bradley, Y. G. Hendrickson, J. Amer. Chem. Soc., 78, 4064(1956).

2) R. E. Parker, N.S. Issacs, Chem. Rev., 59, 737(1959).

3）融点はすべて未補正である.

4） IR スベクトルは日立 EPI-510を用いて测定した,

\section{2 実験および結果 ${ }^{84)}$}

2.1 trans-4-メトキシスチルベンオキシド[I]

[1]（mp 81 $82^{\circ} \mathrm{C}, n$-ヘキサンから再結晶）は Curtin らの 方法によって合成しだ。

\section{2 [1]のクロロホルム中安息香酸による反応1}

[1] $1 \mathrm{~g}$ をク口ロホルム $10 \mathrm{ml}$ に溶かし、これに $1 \mathrm{~g}$ の安息 香酸のクロロホルム溶液 $5 \mathrm{ml}$ を加え室温で 2 日間かきまぜた。
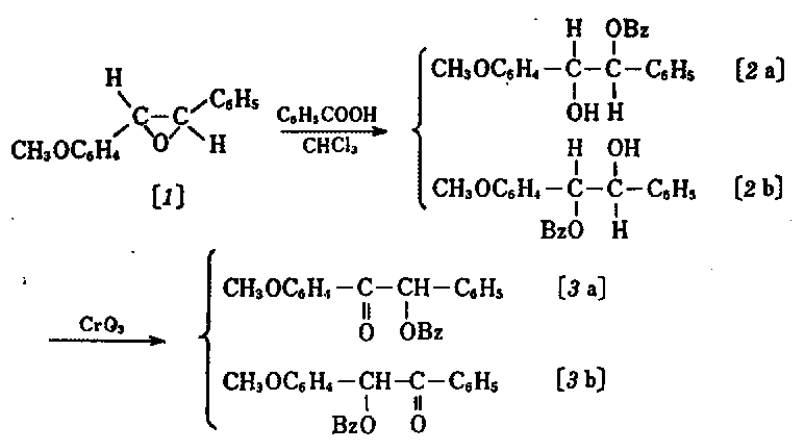

Fig. 1 Ring-opening reactions of trans-4methoxystilbene oxide 